\title{
Making Examples of Women: Juan Luis Vives' The Education of a Christian Woman
}

\author{
by Stephen Derek Kolsky
}

1 .

Juan Luis Vives began writing De institutione feminae christianae [The Education of a Christian Woman] in 1522. It was completed the following year and appeared in print in January $1524 .{ }^{1}$ For the writer personally, this period coincided with a particularly acute crisis that marked a critical turningpoint in his career: the death in 1521 of his patron (William of Croy) which left him in an extremely precarious financial position. ${ }^{2} \mathrm{He}$ was, however, the recipient of a small pension from the queen of England (Catherine of Aragon); a factor which, along with his desire-cum-necessity to visit the monarch in person, provided the stimulus behind The Education. ${ }^{3}$ There is no evidence to support the prevailing view that the choice of argument can be explained in terms of a commission from the monarch. ${ }^{4}$ An unfounded 1 See Juan Luis Vives, The Education of a Christian Woman. A Sixteenth-Century Manual, ed. Charles Fantazzi (Chicago: Chicago UP, 2000), 12-16. All translations will be from the critical edition, J. L. Vives, De institutione feminae christianae liber primus, ed. C. Fantazzi and C. Matheeussen (Leiden: Brill, 1996) and J. L. Vives, De institutione feminae christianae liber secundus \& liber tertius, ed. C. Fantzzi and C. Matheeussen (Leiden: Brill, 1998). The references will contain book number, paragraph, followed by page number. Vives himself states in a letter to Erasmus dated 15 August 1522, "that now that Augustine [his commentary on the Civitas dei] has been out of my hands for three days, I have begun another book [most probably The Education] (The Correspondence of Erasmus. Letters 1252 to 1355.1522 to 1523, trans. R.A.B. Mynors, annotated by James M. Estes (Toronto: Toronto UP, 1989 , letter 1306, p. 162).

2 See Erasmus's letter to Guillaume Budé (16 February 1521, letter 1184) in which he states: "I fear our friend Vives has lost a patron for whom he will be hard put to find a match" (The Correspondence of Erasmus. Letters 1122 to 1251.1520 to 1521, trans. R.A.B. Mynors, annotated Peter G. Bietenholz (Toronto: Toronto UP, 1988), 153.

$3 \quad$ Henry de Vocht, "Vives and his visits to England", Monumenta Humanistica Lovaniensia 4 (1934), 1-60; Carlos G. Noreña, Juan Luis Vives (The Hague: Nijhoff, 1970), 70-80; Juan Luis Vives, The Instruction of a Christen Woman, ed. Virginia Walcott Beauchamp, Elizabeth H. Hageman, Margaret Mikesell, Sheila ffolliott, Betty S. Travitsky, Denise Albanese, Anne M.Haselkorn, Janet S. Gross, and Caren A. Pauley (Urbana: Illlinois UP, 2002), xx-xxvi; Eugenio M. Olivares-Merino, "A month with the Mores: The meeting of Juan Luis Vives and Margaret More Roper", English Studies, 88 (2007), 389-90, 397.

4 Vives, The Instruction of a Christen Woman, xxiii. For example, Garrett Mattingly, Catherine of Aragon (New York: Book-of-the Month Club, 1990; $1^{\text {st }}$ ed. 1941), 184. 
hypothesis, the claim is perhaps often repeated because it purports to "explain" why Vives wrote a text that was so out of character for him; so different from his previous work. The Education can more properly be seen as the founding work in his series of investigations into the nature of society and its major institutions. However Vives is caught in a delicate double bind: dedicated to the queen of England but insistent on a subordinate, submissive role for women, the text must take care to expound its message not only without alienating the queen but rather, indeed, with the goal of winning her favour.

It is the thesis of this article that Vives attempts to combine these two purposes (the pursuit of royal patronage and the control of women within a rigid patriarchal schema) by acknowledging and building upon Catherine of Aragon's reputation for deeply held religious beliefs and considerable learning. ${ }^{5}$ In this way the general criticisms he levels at "non-decorous" or "indecent" behaviour will, in theory, become acceptable as a means of correcting the failings of both court society and the bourgeois family. Vives introduces the ideal of the bourgeois housewife (whose values infiltrate all levels of society) as a counterweight to the court lady. It will be argued here that the text is frequently self-contradictory as a result of the recognition of the superiority of bourgeois ideals over those of the aristocratic, court-based woman. The powerful woman is not entirely expurgated from the text but she remains hidden deep in the shadows, emerging only occasionally, framed in a complex grid of classical and Christian exemplary female figures. When she does make an appearance she is hedged about with repressive limitations to her behaviour, and not even the queen is exempted from this.

5 Erasmus' view of the queen is close to the one outlined in The Education: he describes her as a "model in this century of a true piety" who "consecrates a good part of the day to sacred scripture" and as "a woman of refined culture" quoted in Anne M. O'Donnell, "Sixth annual Bainton lecture: Contemporary women in the letters of Erasmus," Erasmus_of Rotterdam Society Yearbook 9 (1989), 34-72 (43, 44). 
2.

In view of Vives' own intention to take a wife (he married Margarita Valdaura in 1524$)^{6}$, the Education may also be viewed as a meditation on marriage: it expresses the writer's fears of the negative consequences the institution may have for men and the terms under which it would become acceptable. The Education expresses the anxieties of a man who is about to embark upon a rites of passage; a textual, metaphorical crossing (as well as an imminently literal one, to England). From this liminal space the as yet unmarried author views women as a sexual danger to both himself and other men in terms of intellectual integrity (reason vs. passion). The text avoids overtly entering into the murky, polemical waters of celibacy (unlike Erasmus) because it is simply not a choice for Vives' "perfect" man or woman whose life is to be conducted in civil society (the model for which is possibly the Low Countries, particularly the city of Bruges). The Education is therefore conceived as a series of restrictions and limitations that circumscribe women and guard against their potentiality as the intellectual equals of men; thereby diminishing the dangers to the wellbeing, and maintaining the humanistic superiority, of the latter. Feminist critics, along with other observers of the text, have reiterated the point in recent years that the ideal woman of The Education is enslaved within a strict regime, the consequences of which make her entirely subject to male governance and quasi invisible to the public world. ${ }^{7}$ More nuanced readings, however, detect an ambivalence in the attitude of the text towards women. ${ }^{8}$

6 Carlos G. Noreña, Juan Luis Vives and the Emotions (Carbondale: Southern Illinois UP, 1989), 42.

7 Gloria Kaufman, "Juan Luis Vives on the education of women," Signs: Journal of Women in Culture and Society, 3 (1978), 891-96; Constance Jordan, Renaissance Feminism. Literary Texts and Political Models (Ithaca: Cornell UP, 1990), 11719. The most forceful expression of such a view comes from István Bejczy, "Vivès et l'éducation des femmes: redressement du bilan", Neulateinisches Jabrbuch-Journal of Neo-Latin Language and Literature, 3 (2001), 11-28.

8 Nancy Weitz Miller, "Metaphor and the Mystification of Chastity in Vives's Instruction of a Christen Woman," Menacing Virgins: Representing Virginity in the Middles Ages and Renaissance, ed. Kathleen Coyne Kelly and Marina Leslie (Newark and London: Delaware UP and Associated UP, 1999), 132-45; Valerie Wayne, "Some Sad Sentence: Vives' Instruction of a Christian Woman," Silent but for the Word. Tudor Women as Patrons, Translators, and Writers of Religious Works, ed. Margaret Patterson Hannay (Kent, Ohio: Kent State UP, 1985), 15-29; Edna N. Sims, 
This sense of contradiction can be discerned in The Education as part of a textual incoherence that fails to marry classical exempla with Vives' contemporaneous emphasis on the housewife enclosed in the private world of her husband. ${ }^{9}$ In part this is because contradictory signals have been perceived through the conflicted deployment of exempla; that is, classical exempla are suggestive of horizons beyond the marital prison and the constrictive effect of the chastity ideology; at least for modern readers. ${ }^{10}$ In other terms, Vives' attempt to produce a thoroughly closed text has partially failed because he is not brief enough. The numerous examples he provides lead to what Suleiman calls "the overflow effect"; ${ }^{11}$ that is, his desire to totally envelop women within a single virtue that prevents their participation in social life is challenged by his use of classical exemplum. ${ }^{12}$ Some examples or elements of these exempla demonstrate that, historically, particular women were able to exercise far greater power than allowed for or envisaged by the writer for the women of his times - ambiguity derives from the conundrum of contemporary literary or, more especially, "powerful" women who are acknowledged by the text, but whose basis for action is undermined by the opposing model of wifely and "homely"

"Alfonso Martínez and Juan Luis Vives", College Language Association Journal, 18 (1974), 52-68 (65-6).

9 Janis Butler Holm, "Struggling with the letter: Vives's Preface to The Instruction of a Christen Woman" in Contending Kingdoms: Historical, Psychological, and Feminist Approaches to the Literature of Sixteenth-Century England and France, ed. Marie-Rose Logan and Peter L. Rudnytsky (Detroit: Wayne State UP, 1991), 265-97.

10 Pamela Joseph Benson, The Invention of the Renaissance Woman. The Challenge of Female Independence in the Literature and Thought of Italy and England (University Park, Pennsylvania: Pennsylvania State UP, 1992), 174-79.

11 Susan Rubin Suleiman, Authoritarian Fictions. The Ideological Novel as a Literary Genre (New York: Columbia UP, 1983), 206.

12 See Joaquín Beltrán Serra, "Tratamiento de las fuentes clásicas en Vives: De institutione feminae christianae I," Congreso Internacional sobre Humanismo y Renacimiento (Universidad de León 1996), ed. Maurillo Pérez González, Juan Matas Caballero, vol. 2 (León: Universidad de León), 195-202 and Idem, "Fuentes clásicas en Vives: De inst. fem. chris. II-III," La filología latina hoy. Actualización y perspectivas, ed. Ana M.a Aldama Roy, M.a Felisa del Barrio Vega, Matilde Conde Salazar, Antonio Espigares Pinilla, M.a José López de Ayala y Genovés, vol. 2 (Madrid: Sociedad de Estudios Latinos, 1999), 791-97. 
behaviour. ${ }^{13}$ For the latter Vives lays down a basic, precise moral pattern in the shape of a dualist model whereby women are judged either good or bad according to both the dictates of decorum and decency, and their submission to male subjugation within a broad Christian framework. Vives generally accepts female literary activity as long as it is cooperative and supportive of the "correct" male ideologies (I, 35,51 ). It should be noted here that St Jerome (one of Vives' most significant sources) employed classical exempla, some of them cited by Vives, to make points about female morality. Thus The Education could be regarded as a reworking of Against Jovinianus but in support of marriage. Both these writers, therefore, can be seen as having played down any practical repercussions, apart from the moral, on women's lives.

The exemplum of Hortensia ${ }^{14}$ (I, 24, 33) is especially relevant to the argument. Her intrepidity, including the employment of oratorical skills in the public arena, could well have been portrayed as a primary negative example of inappropriate female behaviour (Vives does not accentuate the role of chastity in her public performance). But there is not a trace of negativity to be found: her eloquence (so soundly deplored in other women in The Education) becomes a model for literary imitation, on a par with Cicero or Demosthenes. In this Vives is following Quintilian, but even here he adds details that make Hortensia's achievement all the more praiseworthy and, surprisingly, he "outdoes" the Roman writer in his praise of her. ${ }^{15}$ Indeed, going against the grain, Vives bestows approbation upon the female orator

$13 \quad$ Alexander Gelley, "The pragmatics of exemplary narrative" in Unruly Examples. On the Rhetoric of Exemplarity, ed. Alexander Gelley (Stanford: Stanford UP, 1995), 152-4; Suleiman, Authoritarian Fictions, 149-55.

14 Joyce E. Salisbury, Encyclopedia of Women in the Ancient World (Santa Barbara, California: ABC-CLIO, 2001), 161-62; Cheryl Glenn, Rhetoric Retold: Regendering the Tradition from Antiquity through the Renaissance (Carbondale: Southern Illinois UP, 1997), 67-70; D. Alexis Hart, "Hortensia (ca.70s-10s BCE)" in Classical Rhetorics and Rhetoricians: Critical Studies and Sources, ed. Michelle Ballif and Michael G. Moran (Westport, CT: Praeger Publishers, 2005), 219-22.

15 Quintilian notes only that Hortensia's speech "is still read and not merely as a compliment to her sex", Institutio oratoria Books I-III, trans. H. E. Butler (Cambridge, Mass.: Harvard UP, 1920; repr. 1996), I, 1, 6. 
in a comment that until now has not been given due consideration: "But I would not necessarily condemn in this sex the eloquence that Quintilian, followed by St. Jerome, considers worthy of praise in Cornelia, mother of the Gracchi, and in Hortensia, daughter of Quintus Hortensius, and in Eunomia, daughter of Nazarius" (II, 28; 41). ${ }^{16}$ The juxtaposition of Hortensia with Cornelia is significant in that the latter is introduced early on in the text $(\mathrm{I}, 11,17)$ by way of a quotation from Tacitus, the principal point of which is to demonstrate the "strict discipline" on the part of the "chaste mother" required to produce leaders. Cornelia represents the "spirit" of the "good old days" (I, 11, 17); that is, of a time before basic principles had been vitiated by excessive luxury and a lack of feminine virtue. This is a constant theme of The Education through which the author sets up a dichotomy between past and present; a strategy which permits him to criticize current behaviour whilst simultaneously creating a restrictive model for all women based on a return to early principles, both Christian and pagan (I, 60, 85).

Vives' basic assumption is that women are required to be docta [learned] to the extent that this will guarantee their chastity. His listing of such women appears to be straightforward in this respect; for example, Cleobulina "spent her life so dedicated to literature and wisdom that she abstained from carnal pleasure and remained a virgin" (I, 23, 33). Vives' list can be seen as a conscious effort, through repetition, to emphasize the virginity of the pagan women whose achievements could otherwise be viewed as a serious threat to male domination of the written word. However the listing becomes problematic when the writer enters into the "grey" area which celebrates the literary achievements of pagan women in the public arena. What are we to make, for example, of the exemplum of Corinna of Tanagra who "defeated the poet Pindar five times in poetic contests"? (I, 24, 35). Corinna's unemphasized chastity apparently places her in a different $16 \quad$ The Christian example is only added in the 1538 edition. On Eunomia see In praise of Later Roman Emperors: the Panegyrici Latini : Introduction, Translation, and Historical Commentary, with the Latin text of R.A.B. Mynors, ed. C.E.V. Nixon and Barbara Saylor Rodgers (Berkeley: California UP, 1994), 334 n.1. 
category from the unchaste and much-criticized Leontion. Indeed, Vives had erected a Manichean divide in women's writing between the chaste and the unchaste; a division that was present and validated in the dedication where the queen herself is set against the negative example of Leontion. The paradox is this: readers of The Education are presented with evidence that women have been (ergo are) capable of writing and participating in public life, ${ }^{17}$ yet Christian women are prohibited from expressing themselves and especially from speaking outside the home (I, 105, 143). Vives attempts to reconcile what appear to be two competitive models of female behaviour. The pagan other, that could be seen to operate outside Christian parameters, is subject to a textual vigilance that aims at bringing it closer to Christian mores in matters of chastity and virginity. Pagan exempla are often viewed as substitutes for Christian ones in that Vives thereby justifies the study of ancient texts: he demonstrates their proper usage as moral tools, ignoring some incongruences because the reader will have learnt or absorbed Christian doctrine. In this sense The Education trains its readers how to read.

The classical exemplum has been part of the humanist baggage in any discussion on women since Boccaccio's De mulieribus claris. The standing of ancient examples is ambiguous: on the one hand they can show up the failings of Christian women, and on the other demonstrate serious flaws in pagan culture. But above all, they deal with exceptional women whose status allows the moral message to carry a high degree of authoritative conviction and persuasion. The same holds true for some early Christian exmaples. The case of "Eudocia, wife of the Emperor Theodosius the Younger, who was no less renowned for learning and virtuous life than for her rule" (I, 25, 37) indicates that learning is certainly not out of place in a Christian queen, but only when connected to feminine virtue. If The Education has as one of its fundamental aims the promotion of a model for

17 On the readership of The Education see Edward V. George, "Persuading a feminine Audience? Gratuitous invective apostrophe in Juan Luis Vives' On the Education of a Christian Woman," Scholia: Studies in Classical Antiquity 5 (1996), 94-111 (95-96). 
bourgeois marriage, then these historical exempla are in stark contradiction to the rest of the text: literature does not have the same limits in the ancient exempla providing it is "sober and chaste", as set out in the conditions imposed on modern women (I, 19, 27). The more authoritarian model for present-day women can be accounted for in part through Vives' perception of the decline of Christian values in current society; by the on-going failure of females to read the "right" books, especially the Church Fathers (I, 22, 31). The contemporary examples also effectively reveal women who basically can be divided into two categories: the bourgeois housewife (the principal subject of Vives' rule-making) and the "anomaly" (the woman who, like a queen, exerts some form of power) for whom exceptional behaviour is possible but resisted by the text. It is resisted by making two kinds of hypotheses about all women: the first that she is inferior to Man in all respects in accordance with Aristotelian biology (II, 24, 31, 33), ${ }^{18}$ and the second that all wives are required to behave in a similar manner towards their husbands regardless of their status. Discussing his future mother-in-law, whose devotion to her husband borders on the pathological (demonstrating an "exemplary" denial of the self), Vives writes: "But these are the actions of low-born women," some noble lady will say. First of all, Clara Valdaura was not at all of lowly origin. She was young, very beautiful, refined and had many servants to whom she could have assigned a great part of these duties if she had been willing. But there are many noble women who lend themselves to these same services, both of our own day and from the past, all of whom I cannot enumerate (II, 40, 47).

Vives' future mother-in-law is the object of an extensive paean lauding her exemplary devotion (or self-abnegation). This (probable) eyewitness account appears to take delight in Clara Valdaura's "heroism" in tending her husband who is suffering from the "French pox" (II, 36, 45). No other attributes are mentioned with respect to her life; the fact of having borne children adding further to her representation as "an exemplar" (II, 39, 47).

$18 \quad$ María Luisa Femenías, "Women and natural hierarchy in Aristotle", Hypatia 9 (1994), 167-68. 
The question of female patronage comes into the picture at this juncture. Whilst the opportunity of entering the circle of Catherine of Aragon may have had the potential to rescue Vives economically, it also complicated matters as far as his exposition of marriage and the role of women were concerned. He cannot simply ignore the fact that Catherine is the queen of England - not a bourgeois housewife! The preface to his work emphatically underlines that "a woman's only care is chastity" (I, Preface, 5). In this way the queen becomes an emblem for the ideal woman, but such reasoning cannot be straightforwardly maintained throughout the text. Vives' attempt to close down the tract has the potential to open it up. Whatever else queens may or may not do, they all operate in public and wield differing levels of political power. This upsets the balance of the text, which cannot be called a compromise between the two positions. If there is recognition of actual, contemporary women exercising power, Vives attempts to embed them in the mainstream discourse he has set up, thus obviating the danger to men. Herein arises the contradictions of the text: the imposition of "bourgeois" values onto aristocratic behaviour results in a number of pressure points that render the attempted amalgam unstable.

Vives uses a small number of contemporary exempla (drawn from his own family and experience) to present non-aristocratic models of female behaviour that can be read as correctives to aberrant conduct. These are central to his idealization of the bourgeois housewife. ${ }^{19}$ They offer a counterweight, or Christian revision, to the classical exempla and, although sometimes longer, are fewer in number than either the classical or Christian exempla. Moreover, he provides two direct examples of contemporary married women whose conduct is held up as exemplary. They are the object of narratives that illustrate the way in which the author fashions these women, banishing from their representation even the minimum of autonomous selfhood - unlike some of the pagan women who threaten to develop (or have even devel-

19 Vives also presents negative examples of wifely behaviour ("Flemish wives") for the same purpose of correction (for example, II, 66, 81). 
oped) an individual subjectivity. Roberte Le Lieur (not named in the text except as the wife of Guillaume Budé) is presented as the model wife for a humanist: ${ }^{20}$ significantly, she is not present during a conversation between Vives and Budé but passes through the vestibule, a shadowy or ghostly figure whose main role is that of "a prudent mistress of the household" (II, 54, 67). "She greeted her husband with due respect" Vives tells us, before adding a telling comparison with Pliny's wife (also not named) whose respect for her husband was based on knowledge of his studies, which was certainly not the case for Roberte Le Lieur. Vives can thus be seen as reversing the position he held in Book I regarding the necessary connection between reading, studying and chastity. The implication is that the wife, in reality, is required only to have a passive acceptance of the vital importance of her husband's learning; Vives applies the adjective "heroic" to her, thus transferring the values of the virago to the household (II, 54, 67). Such a transformation, in which children and books (respectively "liberos" and "libros" in Latin) become almost interchangeable for this new heroine, is further underlined by the distancing effect achieved by the textual quotation from one of Pliny's epistles about his wife: "she sings my verses and sets them to the cithara" (II, 53, 67). In fact the exemplum of Budés wife is the "culmination" of a series of examples involving the shaping of the spouse according to her husband's desires. ${ }^{21}$ Pliny's wife stands in contrast to Roberte le Lieur insofar as her form of "adaptation" to her husband is more active, in line with the key features of the classical exemplum. The pagan wife, unlike the Christian bourgeois woman, is not closed off from the outside world.

The exemplum of Roberte le Lieur offers an actual model of the humanist's wife - an important stimulus for someone like Vives who most likely was considering marriage at the time of, or even prior

20 David O. McNeil, Guillaume Budé and Humanism in the Reign of Francis I (Geneva: Droz, 1975), 7-8.

21 "So a wife should adapt herself to her husband's character and interests and not hate or despise them" (II, 53, 67). 
to, the composition of The Education..$^{22}$ Fear of being kept from one's studies (especially if caused by a spouse's desire for material fulfillment) is doubtless a motive that impelled him to lay down harsh rules and regulations concerning wifely behaviour. ${ }^{23}$ Budés wife appears incidental to the entire proceedings but her presence makes possible the relationship between the two humanists. Her devotion to her husband allows a humanistic, homosocial bond based on knowledge to exist between Vives and Budé, assured in their superiority. This model wife demonstrates the requisite respect to the two men - she has been "domesticated" so that her sexual instincts will not endanger the rational world of the humanists. ${ }^{24}$ By suppressing in females any element of behaviour that could be regarded as seductive, men will themselves be freed from the responsibility of their own sexuality while, at the same time, being able to continue defining Woman as subject to sexual urges. ${ }^{25}$ The length of the narrative corresponds to the type of heroic behaviour Vives was seeking to instil in wives: neither Clara Valdaura nor Roberte Le Lieur are depicted outside their homes, nor do they have any concerns other than to conform to the will of their husbands.

The authorial commentaries attempt to smother and "rectify" any anomalies that surface due to differences between classes, or between pagan and Christian attitudes. The text attempts to reduce women to Woman by attributing to them not only a physi$\mathrm{cal} /$ physiological identity but also common occupations and roles throughout history. The ideal woman is meant to supersede class and individuality; she is dispossessed of "her embodied and unrepeatable

22 Juan Luis Vives, Epistolario, ed. José Jiménez Delgado (Madrid: Editora Nacional, 1978), 357.

23 Epistolario, 477. See also Noreña, Juan Luis Vives and the Emotions, 44.

24 Federica Parenti Pellegrini, "Juan Luis Vives: il debito coniugale e la moglie come animale domestico", Archivio Storico Italiano, 571 (1997), 495-506. See also Epistolario, 521-23, where Vives compares the husband's treatment of his wife to the taming and control of a horse. Cf. I, 55, 79 and and J.L. Vives, De officio mariti, ed. C. Fantazzi (Leiden: Brill, 2006), Preface, 5, 7.

25 The process, of course, starts well before marriage so that by the time a woman marries she has been thoroughly trained. See I, 45, 65 where Vives recommends fasting to "extinguish the fires of youth". 
uniqueness" . ${ }^{26}$ Particularly relevant to the discussion is Cavarero's remark that "one cannot ask Woman who she is, but only what it is" (Cavarero, 50). Indeed, The Education reduces women to whatness with the aim of eliminating their whoness. Woman is the object of general rules and regulations, applicable to all, that do not allow for subjective autonomy. The paradox is that a minority of the classical examples interrogate the generalization of female perfection, creating the potential for a subjectivity that resists the rule-making activity of the text as a whole. However this aspect must not be exaggerated since even those exempla that permit of alternative readings, including those concerning female rulers, impose stringent restrictions since the male voice of the text insists on levelling dissonant voices, crowding them out with ever more correct examples and precepts.

The complexities alluded to above are well illustrated by the near-contemporary exemplum of Maria, duchess of Burgundy, and her husband, the emperor Maximilian (II, 60, 73). On this rare occasion Vives tackles the delicate, almost distasteful question of a powerful woman. The example falls into three parts that do not necessarily form a logical or coherent whole. Firstly, the duchess could have taken all political decisions by herself (especially as she had the support of the people "as if she were their leader") but she chose not to execute even those decisions that were within her power, as she regarded her husband's will as law (II, 60, 73). Secondly, she was able to " administer everything according to her own wishes" because of the implication that Maximilian was lacking in masculine virtues and leadership skills. The text does imply that the couple's loving relationship was the basis for this "exchange" of powers, yet it also recognizes that Maria was prudentissima [extremely prudent]. Thirdly, the conclusion is not unexpected given the context in which this modern exemplum is placed. It is worth quoting in full: "In this way Maria in a short time added much to his authority, enhancing his power, and that region became more obedient to its rulers, since respect for them

$26 \quad$ Adriana Cavarero, Relating Narratives: Storytelling and Selfhood (London: Routledge, 2000), 33. 
was doubled, the sovereignty of the one supported and sustained by the other" (II, 60, 73)). The significant point is that Maria works for her husband, not for herself. It does not appear to have been a shared arrangement in the first instance, nor is it a form of amicitia (apart from the phrase "geminata reverentia" [doubled respect] which suggests that her political work enhances the reputation of them both). In the context of Vives' discussion, Maria of Burgundy's political nous is used exclusively in support of her hapless husband. Yet there is a discordant note here. The preceding classical exempla are much more clearly univocal in their depiction of women who have refrained from asserting their nobility despite marrying "beneath them", who, indeed, have revelled in their "demotion"; there is no overt reference to a similar attitude in Maria's case. ${ }^{27}$ She is, perhaps, the limit of female public achievement that can be summarized as an acknowledgement that royal/aristocratic women may occasionally have greater political skills than their husbands. These skills, however, are used solely to further the political goals of their spouses, even if the incontrovertible reality is that the real power resides in the woman. Vives feels the need after this example (simultaneously both explicit and blurred around the edges) to arrive at a concluding statement that is more general and refers axiomatically to all women; bourgeois, aristocratic and royal. He has a compulsion to move away from an ambiguous example and clarify his position, despite running the risk of contradiction. He sums up the question of women's political prestige, authority and power as follows: "The prudent woman should not think that the dowry she brings with her into her husband's home consists of money, beauty, or splendour of lineage, but chastity, modesty, moral integrity, obedience to her husband's authority, diligent care of her children and of the house" (II, 60, 73, 75). One should note that Vives insists on the concept of "domus" - the private realm that deauthorizes female activity outside the house. His insistence on moral and household "virtues" further removes women from a model that

27 Cf. Constance Jordan, Renaissance Feminism. Literary Texts and Political Models (Ithaca: Cornell UP, 1990), 116-19. 
could see them taking power for themselves, thus reducing the fear that they could "dictate terms" to their husbands. Indeed the crucial expression "prudens mulier" (of which the "prudentissima" Maria of Burgundy would be a key example) underlines a shift brought about by gendered power relations between husband and wife, whereby public skills become household, practical skills; the prudence of the wife consisting in a denial of her own potential authority and power. This paradox is caused by the fact that the near-contemporary example of Maria walks a tightrope between a woman ruling autonomously for her country, and one who is obedient to her husband (the implications for the princess Mary are quite clear). The unsaid of the exemplum is critical here: after Maria's death in 1488 the Low Countries rose up against Maximilian I. In this crucial case study, female power is moulded into an acceptable form by the choice of example and the manner of its narration, so that it is ideologically compatible with the basic presuppositions of the text. The first readers of The Education - the current and the future queen of England - have public duties and obligations and the potential to exercise power, whether or not they elect to do so. Thus the text operates to limit that power, accepting it only in conjunction with the discourse on female "weakness" and subordination to one's husband.

Vives is striving to create the "ideal" narrative of Woman, tracing her life cycle, imposing upon her an invariable and controlled destiny, wishing to speak of "her" in the singular. However the text is fractured by the impossibility of this endeavour. It projects a monologic voice even when inserting authoritative quotations, particularly those taken from the Church Fathers. However the constant references to St Jerome could appear ambiguous given that the saint viewed virginity as a higher calling than marriage. ${ }^{28}$ Yet Vives applies Lerome's precepts to his own particular take on marriage, wherein 28 "The difference, then, between marriage and virginity is as great as that between not sinning and doing well; nay rather to speak less harshly, as great as between good and better" in St. Jerome: Letters and Select Works, Against Jovinianus, vol. VI of A Select Library of Nicene and post-Nicene Fathers of the Christian Church, trans. Philip Schaff and Henry Wace (New York: The Christian Literature Company, Parker \& Company, 1893), 358. See also 379. 
chastity becomes as central to his discourse as virginity is in the Jeromian universe. ${ }^{29}$ Indeed the ideal wife of The Education is represented as an asexual being in possession of all the attributes of virginity: procreation is not viewed, nor is it reiterated, as the reason to enter into matrimony; unlike the majority of Christian thinkers for whom child-bearing is the sole motive for people marrying. ${ }^{30}$ An interesting passage from Erasmus' On the Writing of Letters criticizes Jerome's stance on marriage, imputing it to the historical period in which he lived. But Erasmus also suggests that to counteract such a view one needs "a picture of chaste and pure matrimony" (On the Writing of Letters 138). ${ }^{31}$ This Vives provides in The Education, using the Virgin Mary as his model:

She [the young woman] must both appear and be humble, chaste, modest, and upright. In this way she will become acceptable to the Blessed Virgin, of whom her life will be the true and exact reproduction... $(\mathrm{I}, 81,111)^{32}$

$29 \quad$ Cf. Hilmar M. Pabel, "Feminae unica est cura pudicitiae': Rhetoric and the inculcation of chastity in Book I of Vives' De institutione feminae christianae", Humanistica Lovaniensia, 48 (1999), 70-102 (87); Ruth Mazo Karras, Sexuality in Medieval Europe. Doing Unto Others (Routledge: New York, 2005), 48-49.

30 "What is there in all of creation purer, freer from sex and the carnal relations necessary for procreation and the slavery of the body than angelic minds? What expresses this more among mankind than virginity?" (I, 37, 53) This statement is crucial for our understanding of Vives' mindset which insists on the nonsexual aspects of a marriage. This is further expanded in his definition of marriage at the beginning of Book II: "For marriage was instituted not so much for the production of offspring as for community of life and indissoluble companionship' (II, 1, 3). It is "the bond of a most sacred fellowship" (II, 4, 7). Vives hazards an even more personal view despite the weight of dissenting theological opinion: "For my part I cannot understand the reason for this ardent desire for children" (II, 124, 149). Erasmus' rhetorical set-piece in favour of marriage in De conscribendis epistolis (On the Writing of Letters) conventionally sees matrimony as the space for procreation, making it the primary reason to marry (Collected Works of Erasmus. Literary and Educational Writings 3, Vol. 25, ed. J.K. Sowards, Toronto: Toronto UP, 1985, 132, 136).

31 By 1521 Erasmus had reached views similar to those expressed by Vives in The Education after having observed the More family. A letter to Budé of September [?] 1521 (letter 1233) explains his change of heart concerning female education which he now sees as beneficial to women's virtue and refers to the "mutual affection of minds" between husband and wife (The Correspondence of Erasmus. Letters 1122 to 1251.1520 to 1521 , pp. 294-99 [298]).

32 Vives further adds: "The first model to place before herself, as I have said, 
The culmination of this discourse is the kind of marriage that is envisaged by Vives through his interpretation of the Virgin Mary: "She was the first who lived in marriage a life above that of ordinary mortals, without carnal relations, an angelic life, taking not a husband, but a guardian of her chastity" (I, 87, 119).

Pleasure, especially sexual pleasure, is the real enemy in the treatise: it is vilified at every level of the text; it is seen as the breakdown of self-discipline, a weakness which will allow the instinctual side of men to predominate over the rational. The classical exemplum of Zenobia underlines this theme with incontrovertible firmness and conviction. The queen of Palmyra had sexual relations with her husband solely for the purpose of procreation: "she was made pregnant without pleasure" (II, 73, 91). Vives adds the provocative comment that "she was worthy to have children without sexual intercourse" II, 73, 91), thus making an association between her - a pagan ruler - and the Virgin Mary. Yet the text goes on to praise the "extreme" chastity of Christian queens who surpassed even Zenobia by preserving their chastity throughout their married lives (II, 73, 91). ${ }^{33}$ Control and self-control are the two constituent elements of Vives' vision of society. The tightly structured text figures the desire to patrol and limit the lives of women.

is the queen and glory of virginity. Mary, the mother of Christ, God and man, whose life should be the exemplar not only for virgins to follow but for married women and widows as well" (I, 87, 117). Cf. Constance M. Furey, "Bound by likeness: Vives and Erasmus on marriage and friendship" in Discourses and Representations of Friendship in Early Modern Europe, 1500-1700. Ed. Daniel T. Lochman, Maritere López, Lorna Hutson (Farnham, Surrey: Ashgate, 2011), 29-42.

33 Carmen Peraita, “ $\dot{ }$ Zenobia gobernante humanista o Zenobia domesticada? La figura ejemplar de las 'claras mujeres' gentiles en De institutione foeminae christianae de Vives" Bulletin Hispanique, 101 (1999), 19-39. Vives attempts, as he does in other cases, to reduce Zenobia's achievements to her "extraordinary continence" (I, 25, 35) or to make it central to her representation, more important than anything else. He employs two adjectives to delineate her qualities "very learned and wise in the governing of her kingdom" (II, 73, 89; my emphasis). The term "prudentissimam" will be used again to describe the political role of Maria of Burgundy, who will be the model of a woman who rules effectively but apparently without destroying the power relations in the marriage. 
3.

It has been said that the Queen of England is what amounts to an afterthought in The Education; more an absence than a presence. While this is true in terms of the textual space she is allotted, the fact that Vives purposely dedicated the work to her suggests that we need to take more seriously both the way she is presented within the text, and how the text in its entirety is affected by her patronage. Do the models of the bourgeois wife and the royal/aristocratic wife co-exist easily in The Education, or do they cause it to become ideologically unstable? Familiarity with one model and a belief in its efficacy, as evinced by Vives' contemporary exempla and the tone of his precepts, leads one to think that his sole aim was to reduce all women to the same bourgeois/Christian ideal. The problem is that the court, which functioned as a place for social and political interaction, operated as a means of making women visible and indeed an essential part of the political system. Women here acted in public and could play a role in affairs of state. For this reason "ladies of the court or of the palace" (I, $100,135)$ are excoriated in the text because they represent everything a woman should not be: talkative, laughing, affable, participating in conversations with men. Vives' language is particularly harsh when he describes the ethos of courtly behaviour (I, 100, 136-37). It is quite clearly the polar opposite of what we later find described in Book III of Castiglione's Courtier. Indeed the Courtier itself could be defined as a riposte to the arguments expounded in The Education. ${ }^{34}$ Against the court lady Vives pits the bourgeois woman who was meant to spend most of her time indoors and remain in complete ignorance of the outside world. Her silence, and her segregation from men, clearly differentiated her from the court lady. Vives attempts to impose his bourgeois model on the court lady - ceding a minuscule part to the activities of a queen or her equivalent - but subjecting the rest to a

$34 \quad$ Cf. Joachim Leeker, "Das frauenbild in Vives' De institutione feminae christianae und Castigliones Libro del cortegiano" in Juan Luis Vives. Sein Werk und seine Bedeutung für Spanien und Deutschland. Akten der internationalen Tagung vom 14. - 15 Dezember 1992 in Münster, ed. Christoph Strosetzki (Vervuert: Frankfurt Am Main, 1995), 55-74. 
careful revision that sees them solely as virtuous women and, like all other women, subject to men, focused on their chastity, and with no political initiative. Catherine of Aragon is rarely mentioned in the text and, on the occasions when her name does appear, the literary expression is rather generic; although not for that less relevant to our discussion.

In the text itself the queen of England is mentioned (along with her three sisters) on two occasions only, with a passing reference to her mother Isabella I of Spain. One reason for this could be that at the time of writing The Education Vives had never actually met Catherine of Aragon and consequently would have been in possession of relatively few personal details about her. However, in terms of patronage the allusions to her sisters and parents underscore her lineage; and a brief reference to her nephew, the emperor Charles V, serves as a reminder of the powerful connections at her disposal. Such statements are rare in the text and, moreover, attempt to neutralize the political effect of the fact that Catherine's sisters are all queens. Strangely enough (or perhaps not so strangely) there is no mention of Isabella I's achievements as queen; namely, her active political and military role, the unification of Spain, the success of the Reconquista and, most problematically for Vives as a converso [converted Jew], the introduction of the Inquisition that so affected his immediate family. The only point that Vives makes about Isabella is that she taught her daughter sewing and spinning (I, 16, 23). This is presented as the sole modern example of the importance of these arts in the definition

$35 \quad$ See Maurice Kriegel, "Le parcours de Juan Luis Vives: du milieu judaïsant à l'option érasmienne," Revue de l'histoire des religions, 215 (1998), 249-281. What is striking is the fact that Vives mentions both his mother and father in The Education, almost in defiance of the Inquisition, as models of married life (II, 51, 65). However he does reduce the length of the passage in a subsequent edition, perhaps in response to Erasmus' criticisms (Epistolario, 461; see also Charles Fantazzi, "Vives and the emarginati" in A Companion to Juan Luis Vives, ed. Charles Fantazzi (Leiden: Brill, 2008), 65-111 (69-70).

At the date of the composition of The Education Vives' father was being tried by the Inquisition, so even the merest inclusion could be interpreted as a provocation, or an assertion, that a converso family could provide inspiration for how marriage should work. 
of female behaviour. Vives underlines his view that sewing is a fitting pastime for queens and the daughters of emperors. In Catherine's case he makes the connection between spinning and Christian devotion, calling her "the saintly wife of Henry VIII of England" (I, 16, 23). This appellation sets her up as a model for his readers as a woman who legitimizes apparently "humble" activities for all classes, so that even a queen is circumscribed by their ideological implications.

The most extensive reference to the four royal sisters is found in the section devoted to literary women. It is telling that their literary achievements are summarized in just a few words, with an observation on queen Juana who "answered in Latin to the Latin ex tempore speeches that are customarily delivered in every town in the presence of new princes" (I, 26, 37). This is immediately followed by the exceptionally brief comment: "The English say the same of their queen Catherine, sister of Juana". Nothing more is said about the sisters' public speaking skills, their knowledge of Latin, or the conclusions that could be drawn from their role as queens. Instead their public, monarchical functions are undermined, if not minimized, by the text which enters into a eulogy of those qualities that can be generalized to encompass all women:

There were no women in the memory of man of more pure chastity than these four sisters, none with a more unblemished name, and there have been no queens who were so loved and admired by their subjects. None loved their spouses more, none rendered them more compliant obedience, none preserved themselves and their loved ones more blamelessly and more assiduously, none were so opposed to base behaviour and lax morals, none fulfilled to such perfection the ideals expected of the virtuous woman (I, $26,37,39)$.

It is perfectly obvious that political expertise is rendered subordinate to moral virtue. Although Vives cannot completely exclude public activity, he lessens the gap between his two models so that the queen exerts a moral authority over the readership. Crucially Vives marks 
definite boundaries for royal female power, indicating that virtue (chastity) is the main preoccupation of the queen, as it is for all other women. It should be recognized that The Education did not find disfavour with the queen (although she did commission another work on marriage from Erasmus). Indeed Catherine actively sought out his company, "enticed" him into the royal court and, crucially, commissioned a further work from him, De ratione studii puerilis. This later study builds on Vives' directions for general reading by women in The Education but takes into account the particular circumstances of a royal princess (Mary) whose needs as the future queen of England were different from those of other women. ${ }^{36}$ One can deduce, therefore, that a slight but significant change in direction was brought about at the instigation of the queen, as well as by Vives' own assessment of the cultural and political environment of the Tudor court.

In the dedication to The Education, Catherine of Aragon functions as an example ("exemplum" I, 7, 10) of paradigmatic behaviour. And indeed she serves as a model for her daughter, the princess Mary. Catherine is defined as a "domesticum exemplar" (to suggest to Mary both that her mother's example shines forth in a familial setting and also that the values she incarnates are more in keeping with those of the domus (home) than the palatium [palace]). The preface purposely contrasts the saintly figure of the queen with the negative exemplum of Leontion, the sole classical female cited in the dedication. ${ }^{37}$ Leontion, challenging the boundaries of male authority through the assertion of an independent line on marriage, writes "a senseless and shameless tract" against Theophrastus which is savaged equally by classical and Christian authors alike (Preface, 5, 7). The same opposition is presented in the text but treated in a more complex manner: Leontion appears among an initial group of classical women who are learned and sexually "loose". It is not just that the connubium between chas36 See Vives and the Renascence Education of Women, ed. Foster Watson (New York: Longmans, Green and London: Edward Arnold, 1912), 137-49.

37 Preface, 5, 7. Leontion is also discussed in the body of the text (I, 22, 31). See Jane McIntosh Snyder, The Woman and the Lyre: Women Writers in Classical Greece (Bristol and Carbondale, Il., Bristol Classical Press and Southern Illinois University Press, 1991; repr.), 103-05. 
tity and learning is shattered in the figure of the radical Leontion but that this reviled female philosopher espoused Epicureanism, which, for Vives, represented the antithesis of "correct" Christian behaviour; pleasure in all its forms being the target of his acerbic criticism. Further, Vives undermines any sense that Leontion had independent intelligence, or that she was gifted in any way (unlike Boccaccio for instance, who in his De mulieribus claris [About Famous Women], even while condemning Leontion's outrageous sexual behaviour in no uncertain terms, acknowledges that she was in possession of a special gift). ${ }^{38}$

4.

Vives revisits the medieval schema of a female's life - maiden, wife and widow - as the fundamental model for the provision of a complete set of rules for women, from adolescence to death. ${ }^{39}$ It has been argued that he borrowed this arrangement from the late $14^{\text {th }}$-century work The Book of Women [Lo libre de les dones] by Francesc Eiximenis, principally because of the division of women's lives into a basic tripartite structure. ${ }^{40}$ However, there are two salient reasons why this claim is not as convincing as would at first sight appear. Firstly, Eiximenis constructs a quadripartite framework for laywomen that begins with infancy - not a separate category in The Education. Secondly, the greater part of The Book of Women is concerned with females who have 38 Giovanni Boccaccio, Famous Women, ed. Virginia Brown (Cambridge, Mass.: Harvard University Press, 2001), 250-53. Boccaccio states: "We must certainly bewail the fact that so brilliant a talent, bestowed as a sacred gift from heaven, could be subjected to so filthy a way of life" (253; my emphases). This is in direct contrast with Vives' opening statement about Catherine of Aragon: "the holiness of your life and your ardent zeal for sacred studies" (Preface, 1, 3). See also James P. Carley, The Books of King Henry VIII and his Wives (London: The British Library, 2004), $110-11$.

39 The most significant difference between Eiximenis and Vives is that by far the greater part of the former's Lo libre de les dones is dedicated to women who have taken religious vows. León Esteban Mateo, Hombre-mujer en Vives: Itinerario para la reflexión (Valencia: Ajuntament de Valencia, 1994), 29-41. Enrique González González, "Fame and oblivion" in A Companion to Juan Luis Vives, 359-413 (365). $40 \quad J a n$ Papy, "Juan Luis Vives (1492-1540) on the education of girls. An investigation into his medieval and Spanish sources," Paedagogica Historica, 31 (1995), 739-65 (761-65). 
taken religious vows ${ }^{41}$ - Vives excludes such women from consideration, laying his entire emphasis on the centrality of marriage and the subaltern function of women within patriarchy. It is important to underline the radical nature of this exclusion because it means that any emphasis on virginity is instrumental to the main objective; that of a girl entering into matrimony (unlike, for example, St. Jerome who rates virginity more highly than marriage). The text obviously sets out to silence women and police their activities; creating impermeable boundaries between men and women by delineating "superior" and "inferior" sets of duties; by "enclosing" women in a secular sense and making them absolutely obedient to their husbands. The house represents the fulcrum of a woman's activity - even in the case of Catherine of Aragon the palace is purposely and reductively viewed as a home so that the distance between the behaviour of a queen and other women is minimized, indeed to a degree equalized, especially if chastity is meant, in essence, to be the sole characteristic and desired quality of womanhood. Thus Vives creates a system whereby a woman's biography is generalized, fixed, and not permitted to suffer deviations.

The institutio [formation] of the Latin title refers to the genre in which rules and parameters are set up to provide limits and guidance to a specialized profession (such as that of a prince). One can think of Erasmus' Institutions of the Christian Prince which offers instructions for the correct behaviour of a ruler. Vives' calque on Erasmus' title is instructive insofar as Woman is viewed as an all-embracing category that disregards any aspect of distinguishing femininity between one woman and another. In this way difference is effaced and a common standard of behaviour established, leaving women's subjectivity to be formed by men. Furthermore, the title also refers back to Quintilian's

$41 \quad$ Francesc Eiximenis, Lo libre de les dones, ed. Frank Naccarato and Joan Coromines, revised by Curt Wittlin and Antoni Comas (Barcelona: Departament de Filologia Catalana Universitat de Barcelona and Curial Ediciones Catalanes, 1981), 8, 154. The first four sections total 147 pages in the critical edition, while the fifth (on nuns) runs to 364 pages. See David J. Viera, "Influyó el Llibre de les dones, de Francesc Eiximenis (1340?-1409?), en el De Institutione Foeminae Christianae, de Luis Vives?", Boletín de la Sociedad Castellonense de Cultura, 54 (1978), $145-55$. 
Institutio oratoria, not only because there are a number of references to this work in The Education, ${ }^{42}$ but because it underscores the gender differences between the two texts: the Institutio provides guidance in the acquisition of oratorical skills for men who will later perform forensic oratory, whereas The Education could be described as anti-oratorical because it advocates that women be silenced. The opening sentence of Book I of The Education echoes Quintilian's belief that training for one's role should begin immediately after birth. ${ }^{43}$ For the Roman writer, the male student needs to be trained from birth in the skills necessary to the forensic orator. As Vives indicates: "in the matter of morals he [Quintilian] was not so concerned", ${ }^{44}$ whereas for himself morals become the central, if not the only, matter worthy of discussion in relation to women. Thus "training" has two completely contrasting senses in the works of these two writers: for Quintilian it refers to the public career of the orator who is required to perform constantly before an audience and possess a profound knowledge of rhetoric, compared with Vives for whom women are mostly excluded from any sort of public performance. We can characterize The Education as a re-gendered complement to the Institutio oratoria. Vives' text thus gains in prestige and rhetorical power because of its classical antecedent, allowing the writer to create a space whereby the reader can envisage the male space as public, performative and oriented towards the speech act. Against that proposition, underlying the strategy of the text, is the "perfect" woman who inhabits an enclosed, monitored space where selfexpression is not only prohibited but practically (for most women) unattainable. ${ }^{45}$ It is telling that Vives was not completely happy with the title of his own book: he felt that the term institutio could create the wrong impression about the role of women in society, especially since his main preoccupation was with ensuring they act only in private spaces, cut off $\overline{42}$ I, 8, 13; I, 9, 14; I, 13, 19: I, 28, 41; I, 44, 63; I, 63, 101; I, 113, 139;II, 49, 61.

43 I, 8, 13; Quintilian, Institutio oratoria, Books I-III, trans. H.E. Butler (Cambridge, Mass.: Harvard UP, 1996, repr.), 1. 1.21.

44 I, 9, 15. Quintilian is chiefly concerned, with regard to the choice of a nurse, that her speech be of sufficiently high quality to enable her to set a good example for the infant (I. 1. 5).

45 A.D. Cousins, "Humanism, female education, and myth: Erasmus, Vives, and More's To Candidus", Journal of the History of Ideas, 65 (2004), 213-30. 
from all sources of power; woman is not in any sense meant to be an active agent with particular skills, but merely a passive object entirely controlled by her husband. ${ }^{46}$

Vives was intent on establishing as a norm the rigid systematization of a woman's life with an insistence on the absolute exclusion of female pleasure. He thus set about constructing a viable "Christian" alternative to hedonistic court society: "The religion of Christ is not acquainted with courts and kings of this sort" (I, 49, 71). One can note that he excoriates some of the essential features of Renaissance court society: conspicuous consumption, leisure activities, the raised level of political involvement by women - all are either openly attacked or subtly revised (as we have seen in the case of Maria, duchess of Burgundy). Pleasure not only belongs to the lower part of the soul but is one of the driving forces behind the ethos of the Renaissance court. It could include sexual pleasure as well as the more "innocent" activities described, for example, in Castiglione's Libro del cortegiano [Book of the courtier] where women can participate in music, dancing (with some restrictions), singing, spectating at tournaments, and the like. The close interaction between men and women at court, where the latter could play an integral part in politics and be exposed to influences that might endanger their containment, is condemned as "unchaste". Thus what has been described as Vives' "misogynistic rage" 47 is also susceptible to further explanation; that is, the court (also execrated by his fellow Christian humanist Erasmus) was both literally and metaphorically the place where women displayed their physicality and demonstrated their potential, or even actual, access to power (over men). Panic at the thought of women outside of the home, symbolized by dancing, is not just moral panic but also indicates consternation at a possible lack of male sexual self-control; of men being subject to forces that are painted negative and female. In this regard Catherine of Aragon is a paragon, an exemplum of moral leadership for women; someone who could possibly institute a reform of the court and wider society, a renovatio of moral values. Her mastery of spinning is not incidental to the whole project as it confirms

46 Delgado, Epistolario, 344.

47 Vives, The Instruction of a Christen Woman, xxvi. 
a particular Aristotelian attitude towards the home, summed up by the term frugality - the antithesis of courtly magnificence $(I, 17,25)$.

The humanist is attempting a rather awkward synthesis of two contrasting models - royal/aristocratic marriage and bourgeois marriage. He was more familiar with the latter and it provided him with a relatively stable and reassuring model. Yet as previously mentioned, his career opportunities were severely limited, and so royal patronage could not simply be ignored. It was necessary for him to find a means of embedding royal/aristocratic female conduct within a bourgeois framework for the purpose of minimizing the effect of courtly ideals on feminine boundaries: the power such women could wield is not necessarily ignored but remoulded into a different set of values and ideals. These two models lead to an imbalance in the text: female imperfection challenged by female competence in governance and the literary arts (contemporary versus classical exempla), self-restraint versus female (sexual) subversion of male values (the use of cosmetics, dancing etc); companionate versus hierarchical marriage, and so on. The challenge to male power (or even the prospect of sharing it) is thereby reduced when in general terms a woman, any woman, knows her place and limitations. All place needs to be reduced to the domus where the woman can be more easily controlled by her husband. Female decency or decorum becomes a tool with which Vives can rein in any behaviours that represent a potential threat to his humanist vision of life. The Education, paradoxically, walks a tightrope: without offending its patron, it strives to demonstrate the need to subjugate women; offering a picture of Woman that makes as few concessions as possible to the present and the future queen of England. It is this conundrum of the powerful woman that Vives desires to undermine, replacing it, through a total shift of emphasis, with religious and moral matters; and even those remain firmly in the hands of the male members of the family. The Education is determined to be both a reference book for men on how to control their women, as well as an edifying treatise for women to absorb as a source of proper behaviour. 